\title{
PENERAPAN AKUNTANSI SYARÎ'AH BERDASARKAN PSAK NOMOR 59 DAN PAPSI DI PTAI
}

\author{
Wadhan \\ (Jurusan Syarî'ah STA IN Pamekasan, JI. Pahlawan Km.04 Pamekasan, email: \\ wadhanhan@yahoo.co.id)
}

\begin{abstract}
A bstrak:
Akuntansi syarî'ah adalah akuntansi yang berorientasi sosial. Artinya akuntansi ini tidak hanya sebagai alat untuk menerjemahkan fenomena ekonomi dalam bentuk ukuran moneter tetapi juga sebagai suatu metode menjelaskan bagaimana fenomena ekonomi itu berjalan dalam masyarakat Islâm. Prinsip- prinsip umum akuntansi syarî'ah yang menjadi dasar universal dalam operasional akuntansi syarî'ah, yaitu: prinsip pertanggungjawaban, prinsip keadilan, prinsip kebenaran. Operasional bank syarî'ah terdiri dari dua aktivitas utama yaitu kegiatan penghimpunan dana atau pendanaan (funding) dan kegiatan pembiayaan (financial).
\end{abstract}

\section{Kata Kunci:}

A kuntansi syarî’ah, pendanaan, dan pembiayaan.

\begin{abstract}
A bstract:
Syarî'ah accountancy is a social based accountancy. It is not only an instrument to measure economic phenomena in form of monetary measurement but also a method to describe how the economic phenomena applies in Islamic society. There are several general priciples of syarî'ah accountancy that becomes the basic rules in the operation of syarî'ah accountancy, they are the principles of responsibility, justice, and propriety. The operation of syarî'ah accountancy has two activities---the main activity is the activity of accumulating fund or funding and the activity of financing (financial)
\end{abstract}

\section{Keywords:}

syarî'ah accountancy, funding, and financial. 
Penerapan Akuntansi Syan̂'ah

\section{Pendahuluan}

Perkembangan bank syarî'ah di Indonesia semakin pesat seiring dengan meningkatnya kesadaran masyarakat terhadap ekonomi berdasar syarî'ah. Dengan berdasar syarî'ah, bank syarî'ah di tuntut untuk lebih transparan dalam mengungkapkan segala hal yang menyangkut perputaran dana yang dikelolanya. Tuntutan itu salah satunya harus di dukung oleh implementasi proses akuntansi dan pelaporan yang baik. Dalam meningkatkan integritas laporan keuangan bank maka laporan keuangan tahunan bank wajib di audit oleh akuntan publik, dan untuk memperoleh keyakinan yang memadai atas kualitas hasil audit, maka akuntan publik yang mengaudit bank harus terdaftar di Bank Indonesia. Sesuai dengan Surat Edaran Bank Indonesia No. 7/ 57/ DPbs tanggal 22 Desember 2005 bahwa Kantor Akuntan Publik dan Akuntan Publik yang terdaftar di Bank Indonesia harus memiliki beberapa persyaratan dan diantaranya adalah memiliki pengalaman dan kompetensi audit di bidang perbankan dan sanggup secara terus menerus mengikuti program pendidikan di bidang akuntansi dan perbankan untuk terus memutakhirkan pengetahuan dan pemahaman tentang operasional perbankan atau keuangan syarî'ah. Dalam pendidikan ini selain membahas tentang Pernyataan Standar A kuntansi Keuangan (PSAK) 59 juga membahas penerapannya dalam operasi bank syarî'ah secara faktual serta aspek perpajakan sehubungan dengan transaksi akuntansi perbankan syarî'ah. Akuntansi adalah suatu sistem informasi yang mengidentifikasi, mencatat dan mengkomunikasikan transaksi ekonomi yang terjadi pada suatu organisasi kepada pihak yang berkepentingan.

Terdapat tiga aktivitas akuntansi, yaitu:1 Pertama, aktivitas identifikasi (identifying); akan dilakukan identifikasi terhadap transaksi yang terjadi dan di klasifikasikan dalam transaksi ekonomi atau keuangan atau non keuangan. Kedua, aktivitas pencatatan

WWiroso, Pengantar A kuntansi Syariah dan Laporan Keuangan Bank Syariah, Makalah disampaikan pada Training of Trainer (ToT) Perbankan syari'ah Bagi Dosen Perguruan Tinggi, Kerjasama Departemen Ekonomi Syari'ah Fakultas Ekonomi, Universitas A irlangga dengan Bank Indonesia, Surabaya, 18- 20 Mei 2010. 
Wadhan

(recording); setelah diidentifikasi kemudian di catat secara kronologis dan sistematis dengan ukuran nilai moneter tertentu. Ketiga, aktivitas komunikasi (communicating); akan dilakukan pelaporan dan distribusi terhadap informasi akuntansi yang berupa laporan keuangan kepada para pemakai laporan keuangan.

STAIN Pamekasan yang semula menjadi basis disiplin ilmu ke-tarbiyah-an, sejak tahun 1999 dilengkapi dengan jurusan Syarî'ah, untuk memperkokoh bangunan institusional dalam pengkajian rumpum ilmu keislaman secara komprehensif. Pembukaan program baru memiliki relevansi kuat dan signifikan untuk mengoptimalkan kinerja sumber daya manusia serta mengakomodasi aspirasi dan tuntutan kebutuhan masyarakat yang mendambakan nuansa baru di tubuh lembaga pendidikan Islâm khususnya di Madura. Mengacu pada pokok- pokok di atas dan berlandaskan pada Statuta STAIN Pamekasan serta Keputusan Direktorat Jenderal Pendidikan Islâm sejak tahun ajaran baru 2009/ 2010, STAIN Pamekasan membuka program studi baru "Perbankan Syariah" dalam perjalanannya program studi baru tersebut memperoleh respon yang luar biasa dari masyarakat baik dari hasil interaktif maupun respon langsung yang berupa minat calon mahasiswa baru yang memilih langsung untuk studi lanjut di Program Studi Perbankan Syariah Jurusan Syariah STAIN Pamekasan. Dua tahun Program Studi ini dibuka sudah mendapatkan jumlah mahasiswa yang signifikan. Realitas ini memunculkan beban tanggung jawab yang tidak mudah. Karena itu, Program Studi Perbankan Syariah memandang penting untuk mengembangkan pendidikan akuntansi yang berbasis syarî'ah.

\section{Konsep D asar A kuntansi Syarî'ah}

Perbankan syarî'ah di Indonesia diawali oleh pendirian Bank Muamalat Indonesia pada tahun 1991 yang diprakarsai oleh Majelis Ulama Indonesia (MUI), Pemerintah dan Ikatan Cendekiawan Muslim Indonesia (ICMI) serta beberapa pengusaha Muslim. Sampai akhir tahun 2008 terdapat 5 bank syarî'ah di Indonesia yaitu Bank Muamalat Indonesia, Bank Syariah Mandiri, Bank Mega Syariah, 
Bank Syariah BRI dan Bank Syariah Bukopin. Terdapat 27 bank umum yang membuka unit usaha syarî'ah serta 131 BPR Syariah. ${ }^{2}$

Produk perbankan syarî'ah yang mempunyai spesifikasi tersendiri seperti akad jual beli yang terdiri dari M urabahah, salam,dan Istisna. A kad bagi hasil yang terdiri dari M udlarabah dan M usyarakah, serta sewa yang terdiri dari ijârah dan ijârah muntahiyya bi al-tamlik. Di samping itu perbankan syarî'ah menggunakan akab tabbaru untuk qard, qardl al-hasan, wakalah, kafalah, dan rahn.

Mengakomodasi produk perbankan syarî'ah, maka Ikatan Akuntan Indonesia (IAI) dengan merujuk Standar Akuntansi dan Auditing untuk lembaga keuangan Islâm (Accounting and Auditing Standards for Islamic Financial Institutions) yang dikeluarkan A ccounting and Auditing Organization for Islamic Financial Institutions (AAOIFI), lembaga regulasi keuangan Islâm international yang berkedudukan di Abu Dhabi, maka IAI membuat produk Pernyataan Standar A kuntansi Keuangan (PSA K) Syariah Nomor 59 yang disahkan 1 Mei 2002 dan diberlakukan 1 Januari 2003. Dalam perkembangannya, PSAK 59 tersebut mendapat penyempurnaan dengan dikeluarkan PSAK 101 tentang penyajian pelaporan keuangan syarî'ah, PSAK 102 tentang A kuntansi M urabahah, PSAK 103 tentang A kuntansi Salam, PSAK 104 tentang A kuntansi Istishna, PSAK 105 tentang A kuntansi M udlarabah, PSAK 106 tentang A kuntansi M usyarakah. ${ }^{3}$

Beberapa pendapat ahli akuntansi Internasional tentang keberadaan akuntansi Islâm di antaranya sebagai berikut:4 Pertama, D.R. Scott (1975) sebenarnya tidak secara eksplisit mengemukakan akuntansi Islâm tetapi dia merupakan pelopor perumusan akuntansi berdasarkan pada aspek keadilan, kebenaran, etika karenanya sejalan dengan konsep akuntansi Islâm.

Kedua, T.E. Gambling dan R.A.A Karim (1986) menurut teori kolonial model jika ada masyarakat Islâm, maka otomotis

\footnotetext{
2 Direktorat Perbankan Syariah Bank Indonesia, Statistik Perbankan Syariah (Islamic B anking Statistik), Desember 2008.

3Firdaus Furywardana, A kuntansi Syariah, Mudah dan Sederhana dalam Penerapan di Lembaga Keuangan Syariah, (Yogyakarta: Pendidikan dan pelatihan Perbankan Syariah (PPPS), 2009), hlm. 5-6.

4 Sofyan Syafri Harahap, A kuntansi Islam, (Jakarta: Bumi Aksara, 1997), hlm. 6-8.
} 
Wadhan

ekonominya Islâm dan juga akuntansinya mesti Islâm,..... dalam Islâm dikenal zakat sebagai upaya menyelesaikan masalah sosial. A kuntansi Islâm sangat menekankan pada aspek sosial bukan hanya kepentingan investor atau pemilik modal saja.

Ketiga, Robert Arnold Russel (1986) mengemukakan bahwa sebelum dikenal double entry oleh Pacioli sudah ada sistem double entry A rab yang lebih canggih yang merupakan dasar kemajuan bisnis di Eropa pada A bad Pertengahan.

Keempat, Muhammad A kram Khan (1992) tujuan akuntansi Islâm adalah menghitung laba rugi yang tepat, mendorong dan mengikuti syariat Islâm, menilai efisiensi manajemen, melaporkan yang baik, dan keterikatan pada keadilan dan kebenaran.

Kelima, Muhammad Khir (1992) akuntansi Islâm lebih sesuai dan fully applicable karena akuntansi Islâm dalam masyarakat yang sedang berubah saat ini memiliki peran yang sangat penting yaitu pada aspek kebenaran dan keadilan. Kedua aspek ini merupakan fungsi pertanggungjawaban kepada Allâh, maka secara pertanggungjawaban ini bingkai dengan nilai syarî'ah.

Keenam, Toshikabu Hayashi (1995) membahas akuntansi kapitalis, konsep akuntansi Islâm, perhitungan zakat, dan studi kasus Feisal Islamic Bank di Kairo dan praktek bisnis di Arab Saudi. Dalam membandingkan akuntansi kapitalis dengan akuntansi Islâm, Hayashi mengemukakan perbedaan mendasar antara keduanya. A kuntansi Islâm memiliki "mete rule" yaitu hukum syariat yang digambarkan oleh al-Qur'ân dan Hadîts, sedangkan akuntansi kapitalis tidak memiliki itu. Ia hanya bergantung pada keinginan user sehingga bersifat lokal dan situasional.

Sejarah akuntansi yang ditulis oleh para ahli sejarah barat menunjukkan bahwa akuntansi secara umum atau apa yang dikenal dengan sistem pembukuan berpasangan secara khusus telah tumbuh dan berkembang di Eropa, tepatnya di Italia. Beberapa referensi yang dapat di lihat baik yang berbahasa Arab maupun yang berbahasa Inggris, tidak di dapati penyebutan apa pun tentang apa yang terjadi negara Islâm.

Pandangan Vangermeersch bahwa tempat tumbuhnya sistem pencatatan berpasangan masih di perdebatkan. Ini berarti dia tidak 
menerima bahwa tempat tumbuhnya sistem tersebut adalah di Itali. Sistem pencatatan berpasangan yang dikenal sekarang ini telah di praktikkan secara luas abad XIV di Italia. Pacioli menyebarkan bukunya yang mengandung satu bab tentang akuntansi, yakni pada tanggal 10 Nopember 1494 M.5

Pacioli menyebutkan di dalam bukunya bahwa sistem pencatatan berpasangan telah ada sejak lama, tetapi Pacioli tidak menyebutkan sejak kapan dan di mana sistem telah ada sejak lama.

Manuskrip tahun $765 \mathrm{H} / 1363$ M karya penulis Muslim yaitu A bdullah bin Muhammad bin Kayah AI Mazindarani yang berjudul Risâlah Falakiyah Kitâb al-Siyaqat, tulisan tersebut disimpan di perpustakaan Sultan Sulaiman al-Qanuni di Istambul Turki. Dalam manuskrip dengan nomor 2756 memuat tentang akuntansi dan sistem akuntansi di Negara Islâm. Al-Mazindarani dalam manuskrip tersebut menjelaskan tentang sistem akuntansi yang populer saat itu, dan pelaksanaan pembukuan yang khusus bagi setiap sistem akuntansi, macam- macam buku akuntansi yang wajib di gunakan untuk mencatat transaksi keuangan, dan cara menangani kekurangan dan kelebihan, yakni penyetaraan.

Konsep adanya sistem syarî'ah dapat dijadikan sebagai nilai dasar dalam pembangunan kerangka konseptual sistem akuntansi syarî'ah, rancangannya yaitu sebagai berikut:6 Pertama, Menunjukkan perlunya sistem akuntansi alternatif bagi orang Islâm dengan menguji secara kritis sistem akuntansi konvensional yang dikembangkana berdasarkan pada nilai barat. Kedua, memberikan suatu pemahaman konsep dasar akuntansi syarî'ah yang didasarkan pada syariat Islâm. Ketiga, mengusulkan kerangka konseptual akuntansi syarî'ah dan implikasinya terhadap peran akuntansi muslim.

Beberapa nilai- nilai tersebut di atas akan menjadi lengkap dengan adanya prinsip-prinsip umum akuntansi syarî'ah di bawah ini yang menjadi dasar universal dalam operasional akuntansi syarî'ah, yaitu:7 P ertama, prinsip pertanggungjawaban; selalu berkaitan dengan konsep amanah. Implikasi dalam bisnis dan akuntansi adalah bahwa

5Muhammad, Pengantar A kuntansi Syariah, (Jakarta: Salemba Empat, 2002), hlm. 105. 6lbid., hlm. 106

7lbid., hlm. 11 
Wadhan

individu yang terlibat dalam praktik bisnis harus selalu melakukan pertanggungjawaban atas apa yang telah diamanahkan dan yang diperbuat kepada pihak- pihak yang terkait pada dirinya, wujudnya bisa berbentuk laporan akuntansi.8 Islâm sangat menekankan pada konsep tanggungjawab, walaupun tidaklah berarti mengabaikan kebebasan individu. Ini berarti bahwa yang di kehendaki ajaran Islâm adalah kebebasan yang bertanggungjawab. Manusia harus berani mempertanggungjawabkan segala pilihannya tidak saja di hadapan manusia, bahkan yang paling penting adalah kelak di hadapan Tuhan. Bisa saja, karena kelihatannya, manusia mampu melepaskan tanggungjawab perbuatannya yang merugikan manusia, namun kelak ia tidak akan pernah lepas dari tanggungjawab di hadapan Tuhan Yang Maha Mengetahui. ${ }^{9}$

Kedua, prinsip keadilan; merupakan masalah yang sangat prinsip dalam seluruh aspek kehidupan, tanpa kecuali dalam persoalan bisnis. Menurut prinsip ini, hendaknya setiap orang diperlakukan sama, sesuai aturan yang adil dan kriteria yang objektif rasional dan dapat dipertanggungjawabkan secara moral. Hal ini dimaksudkan agar dalam kegiatan bisnis hak dan kepentingan masing- masing pihak yang terkait perlu mendapat perhatian secara adil dan proporsional. Oleh karena itu, dikatakan pula bahwa keadilan senantiasa menuntut agar tidak boleh ada pihak yang merasa di rugikan apa yang menjadi hak dan kepentingannya. ${ }^{10}$ Tidak saja berupa nilai yang sangat penting dalam etika kehidupan sosial dan bisnis, tetapi juga merupakan nilai yang secara melekat dalam diri setiap manusia.11

\footnotetext{
8 Konsep tanggungjawab dalam Islâm, paling tidak karena dua aspek fundamental. Pertama, tanggungjawab yang menyatu dengan status kekhalifahan- wakil Tuhan di muka bumi. Kedua, konsep tanggungjawab dalam Islâm pada dasarnya bersifat sukarela, tanpa paksaan.

9 Muhammad Djakfar, Etika Bisn is Islam Tataran Teoritis dan Praktis, (Malang: UIN Malang Press, 2008), hlm. 68.

10 lbid., hlm. 117.

11Keadilan dalam kontek aplikasi akuntansi mengandung dua pengertian, yaitu: Pertama berkaitan dengan praktik moral, yaitu kejujuran, yang merupakan faktor yang sangat dominan. Tanpa kejujuran ini, informasi akuntansi yang disajikan akan menyesatkan dan sangat merugikan masyarakat. Kedua, kata adil bersifat lebih fundamental (tetap berpijak pada nilai- nilai etika/ syarî'ah dan moral).
} 
Ketiga, prinsip kebenaran; dalam akuntansi ini jika dilakukan dengan baik maka akan dapat menciptakan keadilan dalam mengakui, mengukur, dan melaporkan transaksi- transaksi ekonomi.

Dalam teori akuntansi syarî'ah dapat meninggalkan kerangka akuntansi konvensional, namun didalam sistemnya sudah dapat dibedakan, adapun kerangka tersebut yaitu teori kepemilikan, teori kekayaan, dan fund theory. Menurut Sofyan Syafri Harahap bahwa akuntansi Islâm itu sudah pasti ada, karena ia menggunakan metode perbandingan antara konsep syariat Islâm yang relevan dengan akuntansi dengan konsep dan ciri kontemporer itu sendiri. Sehingga dia simpulkan bahwa nilai- nilai Islâm dalam akuntansi dan akuntansi ada dalam struktur hukum dan muamalat Islâm.12

Adapun menurut Muhammad Akram Khan (1992) merumuskan sifat akuntansi Islâm, yaitu sebagai berikut:13 (1) Penentuan laba rugi yang tepat; (2) Mempromosikan dan menilai efisiensi kepemimpinan; (3) Ketaatan pada hukum syarî'ah; (4) Keterikatan terhadap keadilan; (5) Melaporkan dengan baik; (6) Perubahan dalam praktek akuntansi.

Dalam pencatatan akuntansi ada pedoman umum yang menjadi dasar dalam melakukan pencatatan yaitu kesamaan antara kekayaan dan sumber kekayaan, atau sering disebut sebagai persamaan dasar akuntansi.

\section{Kekayaan = Sumber Kekayaan}

Secara umum laporan keuangan terdiri dari tiga kriteria besar yaitu aktiva, utang, dan modal. Di dalam laporan akuntansi harus ada kesamaan antara kekayaan dengan sumber kekayaan. Kekayaan perusahaan biasa disebut dengan aktiva (asset). Aktiva menunjukkan bentuk kekayaan yang dimiliki perusahaan. Sumber kekayaan sering terdiri dari sumber yang berasal dari internal perusahaan (Modal/ capital) dan sumber yang berasal dari luar perusahaan yang dikenal

12 Harahap, A kuntansi, hlm. 143.

13lbid., hlm. 145. 
Wadhan

dengan hutang (Liabities). Sehingga persamaan akuntansi dapat dikembangkan sebagai berikut:14

\section{A ktiva $=$ Kewajiban + M odal}

Mempelajari dan menerapkan akuntansi syarî'ah, pada hakekatnya adalah belajar dan menerapkan prinsip keseimbangan (balance) atas transaksi atau perkiraan atau rekening yang telah di catat untuk dilaporkan kepada yang brehak mendapatkan isi laporan. Islâm adalah cara hidup yang berimbang dan koheren, dirancang untuk kebahagian (falah) manusia dengan cara menciptakan keharmonisan antara kebutuhan moral dan material manusia dan aktualisasi sosio- ekonomi, serta persaudaraan dalam masyarakat manusia. ${ }^{15}$

Akuntansi syarî'ah adalah akuntansi yang berorientasi sosial. Artinya akuntansi ini tidak hanya sebagai alat untuk menerjemahkan fenomina ekonomi dalam bentuk ukuran moneter tetapi juga sebagai suatu metode menjelaskan bagaimana fenomina ekonomi itu berjalan dalam masyarakat Islâm. A kuntansi syarî'ah termasuk di dalamnya isu yang tidak biasa dipikirkan oleh akuntansi konvensional. Perilaku manusia diadili di hari kiamat. Akuntansi harus dianggap sebagai salah satu derivasi/ hisab yaitu menganjurkan yang baik dan melarang apa yang jelek. Realitas akuntansi syarî'ah adalah tercermin dalam akuntansi zakat.16

14 Faqih Nabhan, Dasar-Dasar A kuntansi Bank Syariah, Implementasi PSAK N 0.59 dan Pedoman A kuntansi Perbankan Syariah Indonesia (PAPSI), (Yogyakarta: Lumbung IImu, 2008), hlm. 4-5.

15Menurut Iwan Triyuwono, akuntansi syarî'ah merupakan salah satu upaya mendekonstruksi akuntansi modern ke dalam bentuk humanis dan syariat nilai. Tujuannya adalah tercipta peradaban bisnis dengan wawasan humanis, emansipatoris, transedental dan teleologikal. Konsekuensi dari ontologis dari hal ini adalah bahwa akuntan secara kritis harus mampu membebaskan manusia dari ikatan realitas (peradaban) beserta jaringan-jaringan kuasanya, untuk kemudian memberikan atau menciptakan realitas alternatif dengan seperangkat jaringanjaringan kuasa llâhi yang mengikat manusia dalam hidup sehari- hari.

16A kuntansi zakat menunjukkan proses di mana kekayaan diperoleh secara halal oleh perusahaan. Ini merupakan salah satu contoh dari turunan hisab yang merupakan bidang akuntansi. Di samping itu ternayata melalui al-Qur'ân telah menggariskan bahwa konsep akuntansinya adalah penekanan pertanggungjawaban atau accou ntability yang tujuannya menjaga keadilan dan kebenaran. 


\section{A sumsi Dasar A kuntansi Bank Syarî'ah}

Asumsi standar akuntansi untuk bank syarî'ah yang terungkap dalam pernyataan Standar A kuntansi Keuangan untuk bank syarî'ah (PSAK No. 59) adalah tentang konsep dasar penyajian laporan keuangan dan pengakuan pendapatan bahi hasil. Accounting and Auditing Organizations for Islamic Financial Institution (AAOIFI), 2003 memberikan keleluasaan bagi bank yang menerapkan prinsipprinsip syarî'ah dalam kegiatannya untuk menggunakan prinsip accrual basis atau cash basis. Triyuwono, 2001, menekankan bahwa informasi laba dan prosedur akuntansi harus menyajikan pernyataan yang benar dan akurat, didasari data akuntansi yang layak, tidaak bias, dan tidak memihak pada kepentingan tertentu. ${ }^{17}$

PSAK No. 59, dalam kebijakan pengukuran, pengakuan, dan penyajian laporan keuangan mensiratkan bahwa laporan keuangan disusun berdasarkan konsep dasar akrual (acrual basis).18 Laporan akuntansi yang disusun berdasarkan acrual basis memberikan informasi tidak hanya transaksi masa lalu tetapi juga kewajiban pembayaran kas di masa depan dan sumber daya yang merepresentasikan kas yang akan diterima di masa depan.

Berbeda dengan penyusunan laporan keuangan, perhitungan bagi hasil bank syarî'ah menggunakan konsep dasar (cask basis). Cash Basis digunakan dengan pertimbangan kepastian diterimanya pendapatan yang diterima bank syarî'ah. Bank syarî'ah hanya akan mengakui adanya pendapatan bagi hasil atas sesuatu yang sudah pasti menjadi hak pendapatan bagi bank. Sesungguhnya tidak ada yang dapat mengetahui secara pasti apa yang dapat terjadi pada hari esok, berapa pendapatan yang benar- benar dapat direalisasikan kecuali Allâh swt.19

1 TTriyuwono, As'udi, A kuntansi Syariah, M emformulasikan Konsep Laba Dalam Kontek M etafora Z akat, (Jakarta: Salemba Empat, 2001), hlm. 18.

18 A crual Basis adalah konsep pencatatan transaksi diakui pada saat terjadinya, bukan pada saat kas atau setara kas diterima atau dibayar, serta diungkapkan daalam catatan akuntansi serta dilaporkan dalam laporan keuangan pada periode yang bersangkutan.

19 Al-Qur'ân Surat Luqman (31): 34, “Sesungguhnya Allah, hanya pada sisiN ya sajalah pengetahuan tentang hari kiamat, dan Dia-lah yang menurun kan hujan, dan mengetahui apa 
Wadhan

Akuntansi bank syarî'ah disediakan untuk pihak- pihak yang berhubungan dengan perbankan syarî'ah. Dalam kontek muamalah maka pihak- pihak yang berhubungan dengan bank syarî'ah tersebut memiliki tujuan untuk mendapatkan kesuksesan dunia akhirat dengan senantiasa mengharap ridhâ Allâh swt. Menurut (Pedoman A kuntansi Perbankan Syariah Indonesia) PAPSI, 2003, tujuan akuntansi bank syarî'ah adalah untuk menyediakan informasi yang bermanfaat bagi pihak- pihak yang berkepentingan (pengguna laporan keuangan) dalam pengambilan keputusan ekonomi yang rasional. Informasi bermanfaat yang disajikan dalam laporan keuangan antara lain meliputi informasi:20 (1) Untuk pengambilan keputusan investasi dan pembiayaan; (2) Untuk menilai prospek arus kas baik penerimaan maupun pengeluaran kas di masa datang; (3) Mengenal sumber daya ekonomis bank, kewajiban bank untuk mengalihkan sumber daya tersebut kepada entitas lain atau pemilik saham, serta kemungkinan terjadinya transaksi dan peristiwa yang dapat mempengaruhi perubahan sumber daya tersebut; (4) Mengenai kepatuhan bank terhadap prinsip syarî'ah, termasuk pendapatan dan pengeluaran yang tidak sesuai dengan prinsip syarî'ah dan bagimana pendapatan tersebut diperoleh serta penggunaannya; (5) Untuk membantu mengevaluasi pemenuhan tanggungjawab bank terhadap amanah dalam mengamankan dana, menginvestasikannya pada tingkat keuntungan yang layak dan informasi mengenai tingkat keuntungan investasi terikat; (6) Mengenai pemenuhan fungsi sosial bank, termasuk pengelolaan dan penyaluran zakat.

Akuntansi bertujuan untuk memberikan informasi keuangan yang berguna untuk pengambilan keputusan. Agar akuntansi bisa menyampaikan kepada pengguna, maka diperlukan laporan keuangan. Laporan keuangan sekaligus berfungsi sebagai bentuk pertanggungjawaban manajemen terhadap pihak- pihak yang berkepentingan dengan kinerja bank. Oleh karena itu perlu dipenuhi karakteristik tertentu seperti relevan, reliabel, komparabel, dan konsisten. Untuk memenuhi karakteristik di atas maka ditentukan

yang ada dalam rahim. Dan tiada seorangpun yang dapat mengetahui (dengan pasti) apa yang akan diusahakannya besok".

20Tim Penyusun PAPSI, Pedoman A kuntansi Perbankan Syariah Indonesia, (Jakarta: IAI, 2003) 
format lapopran keuangan keungan bank syarî'ah yang terdiri dari:21 (1) Neraca; (2) Laporan laba rugi; (3) Laporan perubahan ekuitas; (4) Laporan arus kas; (5) Laporan perubahan dana investasi terikat; (6) Laporan sumber dan penggunaan dana qardl al-hasan; (7) Laporan sumber dan penggunaan dana zakat, infak, dan shadaqah; dan (8) Catatan atas laporan keuangan.

Operasional bank syarî'ah terdiri dari dua aktivitas utama yaitu kegiatan penghimpunan dana atau pendanaan (funding) dan kegiatan pembiayaan (financial). 22 Pendanaan dalam bank syarî'ah dilakukan layaknya aktivitas mobilisasi dana oleh bank konvensional yaitu tabungan, giro, dan deposito. Bank syarî'ah melakukan kegiatan pendanaan dengan prinsip- prinsip bank syarî'ah. Prinsip yang paling banyak digunakan dalam aktivitas pendanaan bank syarî'ah adalah prinsip mudlarabah dan wadiah. Terdapat tiga bentuk penarikan dana pihak ketiga yaitu:23 Pertama, dana titipan (wadi ah); merupakan dana pihak ketiga yang dititipkan pada bank. Titipan dana dari masyarakat dapat melalui giro dan tabungan. Penggunaan wadiah dalam transaksi pendanaan dengan alasan fleksibilitas pengambilan dana atau faktor keamanan.24 Dana wadi ah diakui sebesar jumlah dana yang dititipkan pada saat terjadinya transaksi. Penerima yang boleh atas pengelolaan dana titipan diakui sebagai pendapatan bank dan bukan merupakan unsur keuntungan yang harus dibagikan. Pengakuan bonus dalam dalam transaksi wadi ah adalah sebagai berikut:25 (1) Pemberian bonus kepada nasabah diakui sebagai beban pada saat terjadinya; (2) Penerimaan bonus dari penempatan dana

21 Nabhan, D asar-D asar A kuntansi,hlm. 22.

22Funding merupakan kegiatan bank dalam mendapatkan dana baik yang berasal dari pemilik, internal bank maupun dari masyarakat dalam bentuk mobilisasi dana masyarakat atau dana pihak ketiga. Sedangkan Financial merupakan kegiatan bank dalam memanfaatkan dan menyalurkan dana masyarakat yang telah terkumpul ke dalam sektor- sektor yang diperbolehkan dalam syariat Islâm.

23Zainul A rifin, D asar- D asar M anajemen B ank Syariah, (Jakarta: Alvabeta, 2003).

24 Menurut PSAK 59, 2002 dan PAPSI, 2003, wadi ah merupakan titipan nasabah yang harus dijaga dan dikembalikan setiap saat bila nasabah yang bersangkutan menghendaki. W adi 'ah ada 2, yaitu Pertama, W adi 'ah Ya- dhamanah merupakan titipan yang selama belum dikembalikan kepada penitip dapat dimanfaatkan ol eh penerima titipan. Kedua, wadi'ah yad-amanah adalah penerima titipan tidak boleh memanfaatkan barang titipan tersebut sampai diambil kembali oleh nasabah penitip. 25N abhan, D asar-D asar A kuntansi, hlm. 40. 
Wadhan

pada bank syarî'ah lain diakui sebagai pendapatan pada saat kas diterima; (3) Penerimaan bonus dari penempatan dana syarî'ah pada bank sentral diakui sebagai pendapatan pada saat kas diterima; (4) Penerimaan bonus dari penempatan dana pada bank non syarî'ah diakui sebagai pendapatan dana qardl al-hasan pada saat kas diterima.

Kedua, partisipasi modal berbagi hasil dan berbagi resiko (non guaranteed account) untuk investasi umum (general investment account/ mudlarabah muthlaqah), bank akan membayar bagain keuntungan secara proporsional dengan portfolio yang didanai dengan model tersebut.26

Ketiga, investasi khusus (special investment account/ mudlarabah mu-qayyadah), bank bertindak sebagai manajer investasi untuk memperoleh fee, jadi bank tidak ikut berinvestasi, investor sepenuhnya mengambil resiko atas investasi tersebut. 27

Terdapat beberapa kegiatan pembiayaan (financial), di antaranya sebagai berikut:28 Pertama, akuntansi pembiayaan mudlarabah. M udlarabah merupakan akad kerjasama usaha antara bank sebagai pemilik dana (shâhib al-mâl) dengan nasabah sebagai pengusaha/ pengelola dana (mudlârib), untuk melakukan kegiatan usaha dengan nisbah pembagian hasil (keuntungan atau kerugian) menurut kesepakatan di muka.

Pembiayaan M udlarabah

\begin{tabular}{|c|c|c|}
\hline Permasalahan & M odal Kas & Modal Non kas \\
\hline $\begin{array}{l}\text { Pengakuan } \\
\text { Pembiayaan }\end{array}$ & $\begin{array}{l}\text { - Saat pembayaran } \\
\text { kas } \\
\text { - Secar bertahap } \Rightarrow \\
\text { setiap tahap } \\
\text { pembayaran }\end{array}$ & $\begin{array}{l}\text { - Penyerahan aktiva ke } \\
\text { pengelola dana } \\
\text { - Secara bertahap } \Rightarrow \text { setiap } \\
\text { tahap penyerahan }\end{array}$ \\
\hline
\end{tabular}

26 M u dlarabah merupakan prinsip kerjasama antara dua pihak pemilik dana (shâhib almâl) dan pengelola dana (mudhârib). Mudlarabah mutlaqah adalah mudlarabah yang memberikan kebebasan kepada pengelola (mudhârib) dalam mengelola invsetasi. 27M udlarabah M uqayyadah adalah akad mudlarabah yang tidak memberikan kebebasan dalam pengelolaan investasi.

28 Furywardana, A kuntansi Syariah, hlm 21-51. 


\begin{tabular}{|c|c|c|}
\hline $\begin{array}{l}\text { Pengukuran } \\
\text { Pembiayaan }\end{array}$ & $\begin{array}{l}\text { - Sejumlah uang } \\
\text { yang diserahkan }\end{array}$ & $\begin{array}{ll}\text { - } & \text { Sebesar nilai wajar saat } \\
\text { penyerahan } \\
\text { - Selisih nilai wajar } \\
\text { dengan nilai buku } \Rightarrow \\
\text { diakui laba/ rugi }\end{array}$ \\
\hline $\begin{array}{l}\text { Kegiatan mulai } \\
\text { berjalan }\end{array}$ & & $\begin{array}{l}\text { - Sejak barang siap pakai } \\
\text { ditreima mudlarib }\end{array}$ \\
\hline $\begin{array}{l}\text { Penurunan setelah } \\
\text { digunakan secara } \\
\text { efektif }\end{array}$ & & $\begin{array}{l}\text { - Tidak langsung } \\
\text { mengurangi jumlah } \\
\text { pembiayaan tetapi } \\
\text { diperhitungkan saat } \\
\text { pembagian hasil. }\end{array}$ \\
\hline
\end{tabular}

Bank/ lembaga keuangan syarî'ah sebagai shahib al-mâl: Pertama, pengakuan pembiayaan sebagai berikut: (1) Pembiayaan mudlarabah diakui pada saat pembayaaran kas atau penyerahaan aset non kas kepada pengelola dana; (2) Pembiayaan mudlarabah yang diberikan secara bertahap diakuipada setiap tahap pembayaran atau penyerahan.

Kedua, pengukuran pembiayaan sebagai berikut: (1) Pembiayaan mudlarabah dalam bentuk kas diukur sejumlah uang yang diberikan bank/ lembaga keuangan syarî'ah pada saat pembayaran; (2) pembiayaan dalam bentuk aset non kas diukur sebesar nilai wajar aset non kas pada saat penyerahan (3) Selisih antara nilai wajar dan nilai buku aset non kas diakui sebagai keuntungan atau kerugian bank / lembaga keuangan syarî'ah; (4) Beban yang terjadi sehubungan dengan mudlarabah tidak dapat diakui sebagai bagian pembiayaan mudlarabah kecuali telah disepakati bersama; (5) Bagi hasil dapat: metode bagi laba (profit sharing) atau bagi pendapatan (revenue sharing).

Kedua, akuntansi pembiayaan musyarakah. M usyarakah adalah akad kerjasama antara dua pihak atau lebih untuk suatu usaha tertentu, di mana masing- masing pihak memberikan kontribusi dana dengan ketentuan bahwa keuntungan dibagi berdasarkan kesepakatan sedangkan resiko berdasarkan porsi kontribusi dana (PSAK 106 Paragraf 4). 
Wadhan

Pembiayaan musyarakah adalah pembiayaan berdasarkan akad kerjasama antara dua pihak atau lebih untuk suatu usaha tertentu, di mana masing- masing pihak memberikan kontribusi dana dengan ketentuan bahwa keuntungan dan resiko akan ditanggung bersama sesuai kesepakatan (Fatwa DSN No. 08/ DSN- MUI/ IV/ 2000).

Pembiayaan musyarakah setelah akad: (1) M usyarakah permanen dinilai sebesar historis setelah dikurangi kerugian (jika ada); (2) M usyarakah menurun, yakni (a) Dinilai sebesar historis dikurangi bagian pembiayaan bank/ lembaga keuangan syarî'ah yang telah dikembalikan mitra (harga jual wajar) dan kerugian dan (b) Selisih nilai historis dan nilai wajar bagian pembiayaan yang dikembalikan diakui sebagai keuntungan atau kerugian bank/ lembaga keuanagan syarî'ah pada periode berjalan; (3) Akad sebelum jatuh tempo diakhiri, pengembalian seluruh atau sebagian modal, selisih nilai historis dan nilai pengembalian diakui sebagai laba sesuai nisbah yang disepakati atau rugi dengan porsi modal mitra; (4) Akad diakhiri pembiayaan belum dikembalikan oleh mitra diakui sebagai piutang jatuh tempo kepada mitra.

Ketiga, akuntansi pembiayaan murabahah. Murabahah adalah menjual barang dengan harga jual sebesar harga perolehan ditambah keuntungan yang disepakati dan penjual harus mengungkapkan harga perolehan tersebut kepada pihak pembeli (PSAK 102 Paragraf 5). Atau jual beli barang sebesar harga pokok barang ditambah dengan margin keuntungan yang disepakati (PBI No. 09/ 9/ PBI/ 2007 tanggal 18 juni 2007).

Pengakuan:

\begin{tabular}{|l|l|}
\hline Harga barang & $\begin{array}{l}\text { Diakui sebagai Asset M urabahah sebesar biaya } \\
\text { perolehan }\end{array}$ \\
\hline $\begin{array}{l}\text { Potongan harga dari } \\
\text { pemasok }\end{array}$ & $\begin{array}{l}\text { Diakui sebagai pengurang biaya perolehan aktiva } \\
\text { murabahah }\end{array}$ \\
\hline
\end{tabular}

Pengukuran setelah perolehan:

\begin{tabular}{|l|l|}
\hline $\begin{array}{l}\text { Aktiva tersedia untuk dijual untuk } \\
\text { murabahah pesanan mengikat }\end{array}$ & $\begin{array}{l}\text { - Dinilai sebesar biaya perolehan } \\
\text { - Penurunan nilai aktiva diakui }\end{array}$ \\
\hline
\end{tabular}




\begin{tabular}{|l|l|}
\hline & $\begin{array}{l}\text { sebagai beban dan mengurangi } \\
\text { nilai aktiva. }\end{array}$ \\
\hline $\begin{array}{l}\text { M urabahah tanpa pesanan atau } \\
\text { pesanan tidak mengikat }\end{array}$ & $\begin{array}{l}\text { - Nilai terendah maka nilai } \\
\text { perolehan atau nilai bersih yang } \\
\text { dapat direalisasi. } \\
\text { - Nilai bersih <nilai perolehan } \\
\text { maka diakui sebagai kerugian. }\end{array}$ \\
\hline
\end{tabular}

Pencatatan:

\begin{tabular}{|l|l|}
\hline Harga pokok & Dibukukan pada perkiraan “A sset M urabahah" \\
\hline Margin & $\begin{array}{l}\text { Diakui/ dicatat pada perkiraan "M argin } \\
\text { M urabahah ditangguhkan" }\end{array}$ \\
\hline Harga Jual & Dicatat pada perkiraan “P iutang M urabahah" \\
\hline
\end{tabular}

Pengukuran dan pengakuan:

\begin{tabular}{|l|l|}
\hline Piutang M urabahahah & $\begin{array}{l}\text { Saat akad } \Rightarrow \text { diakui sebesar biaya perolehan } \\
\text { ditambah keuntungan yang disepakati } \\
\text { A khir periode } \Rightarrow \text { dinilai sebesar nilai bersih } \\
\text { yang dapat direalisasi (piutang penyisihan) }\end{array}$ \\
\hline $\begin{array}{l}\text { Keuntungan } \\
\text { M urabahah }\end{array}$ & $\begin{array}{l}\text { A kad berakhir sama dengan periode L/ K } \Rightarrow> \\
\text { saat terjadinya. }\end{array}$ \\
\hline $\begin{array}{l}\text { A kad melampaui satu periode L/ K } \Rightarrow>\text { secara } \\
\text { proporsional }\end{array}$ \\
(salah satu metode) & $\begin{array}{l}\text { Saat penyelesaian } \Rightarrow \text { bank mengurangi } \\
\text { piutang murabahah dan keuntungan } \\
\text { murabahah } \\
\text { Setelah penyelesaian } \Rightarrow \text { bank menerima dulu } \\
\text { pelunasan, kemudian bank membayar } \\
\text { potongan. }\end{array}$ \\
\hline
\end{tabular}

\section{Bayar Urbun:}

\begin{tabular}{|l|l|}
\hline Urbun & $\begin{array}{l}\text { Diakui sebagai uang muka pembelian } \Rightarrow \text { sebesar } \\
\text { jumlah yang diterima bank }\end{array}$ \\
\hline
\end{tabular}




\begin{tabular}{|l|l|}
\hline & $\begin{array}{l}\text { A pabila barang jadi dibeli nasabah } \Rightarrow \text { diakui sebagai } \\
\text { pembayaran piutang } \\
\text { - Apabila barang batal dibeli nasabah } \Rightarrow \text { dikembalikan } \\
\text { setelah diperhitungkan kerugian bank. }\end{array}$
\end{tabular}

Pengakuan denda (ta'wid): (1) Dikenakan pada nasabah yang Ialai melakukan kewajibannya; (2) Diakui sebagai bagian dana sosial (al-Q ardl al-hasan). Sedangkan denda dalam murabahah: (1) Nasabah mampu tapi tidak mau; (2) Kedisiplinan nasabah terhadap kewajibannya; dan (3) Besarnya sesuai perjanjian.

Keempat, akuntansi pembiyaan bay' al-salam. Salam adalah akad jual beli muslam fîh (barang pesanan) dengan pengiriman dikemudian hari oleh muslam illayh (penjual) dan pelunasannya dilakukan oleh pembeli saat akad disepakati sesuai dengan syarat- syarat tertentu (PSAK 103 Paragraf 5).

Lembaga keuangan syarî'ah dapat bertindak sebagai pembeli dan atau penjual dalam suatu transaksi salam. Jika lembaga keuangan syarî'ah bertindak sebagai penjual kemudian memesan kepada pihak lain untuk menyediakan barang pesanan dengan cara salam maka hal ini disebut salam palarel (PSAK 103 Paragraf 6).

Pengakuan dan pengukuran dalam piutang salam: (1) Piutang salam diakui pada saat modal usaha salam dibayarkan atau dialihkan kepada penjual (PSAK 103 Paragraf 12); (2) Pengukuran modal usaha salam: (a) Modal usaha salam dapat berup kas dan asset non- kas; (b) Dalam bentuk kas diukur sebesar jumlah dibayarkan; (c) sedangkan dalam bentuk asset non- kas diukur sebesar nilai wajar dan nilai tercatat modal usaha non- kas yang diserahkan sebagai keuntungan pada saat penyerahan modal usaha tersebut; (3) Penerimaan barang pesanan diakui dan diukur sebagai berikut: (a) Jika barang pesanan sesuai dengan akad nilai sesuai nilai yang disepakati; (b) Jika barang pesanan berbeda kualitasnya, maka barang pesanan yang diterima diukur sesuai dengan nilai akad dari barang pesanan barang yang diterima nilainya sama atau lebih tinggi dari barang pesanan yang tercamtum dalam akad; atau barang pesanan yang diterima diukur sesuai nilai pasar pada saat diterima dan selisihnya diakui sebagai kerugian, jika nilai pasar dari barang pesanan lebih rendah dari nilai barang pesanan yang tercamtum dalam akad; (c) Jika pembeli tidak 
menerima sebagian atau seluruh barang pesanan pada tanggal jatuh tempo pengiriman.

Dalam hal penyajian: (1) Pembeli menyajikan modal usaha saalam yang diberikan sebagai piutang salam; dan (2) Piutang yang harus dilunasi oleh penjual karena tidak dapat memenuhi kewajibannya dalam transaksi salam disajikan secara terpisahdari piutang salam; (3) Penjual menyajikan modal usaha salam yang diterima sebagai kewajiban salam.

Kelima, akuntansi pembiayaan istishna. Istishna adalah akad penjualan antara al-muntashi (pembeli) dan al-shani (produsen yang juga bertindak sebagai penjual). Berdasarkan akad tersebut, pembeli menugasi produsen untuk membuat atau mengadakan al- manshu' (barang pesanan) sesuai spesifikasi yang diisyaratkan peembeli dan menjual nya dengan harga yang disepakati.

Pengakuan dan pengukuran Istishna: (1) Jika penyelesaian pembayaran dilakukan dengan cara pembayaran dimuka secara penuh, perlakuan akuntansinya mengikuti perlakuan akuntansi transaksi salam, dengan mengubah istilah piutang salam menjadi asset istishna dalam penyelesaian; (2) Jika penyelesaian pembayaran dilakukan bersamaan dengan proses pembuatan asset istishna, adalah sebagai berikut: (a) Biaya ditangguhkan yang berasal dari biaya praakad diakui sebagai asset istishna dalam penyelesaian pada saat akad ditandatangani; (b) Biaya istishna diakui sebagai asset istishna dalam penyelesaian pada saat terjadinya; (c) Biaya istishna paralel diakui sebagai asset dalam penyelesaian pada saat diterimanya tagihan dari subkontraktor sebesar jumlah tagihan dan pada saat yang bersamaan diakui hutang istishna kepada subkontraktor.

Dalam hal penyajian, asset istishna dalam penyelesaian disajikan dalam neraca: (1) biaya yang dikeluarkan bank menggunakan akad selesai; dan (2) Biaya yang dikeluarkan ditambah penyesuaian pada akhir periode jika bank menggunakan metode prosentase penyelesian. Sedangkan termin istishna disajikan sebagai pos lawan dari asset istishna dalam penyelesaian pada neraca.

\section{Penutup}

Dari uraian di atas, dapat disimpulkan sebagai berikut: Pertama, akuntansi syarî'ah adalah akuntansi yang berorientasi sosial. 
Wadhan

A rtinya akuntansi ini tidak hanya sebagai alat untuk menerjemahkan fenomina ekonomi dalam bentuk ukuran moneter tetapi juga sebagai suatu metode menjelaskan bagaimana fenomina ekonomi itu berjalan dalam masyarakat Islâm. A kuntansi syarî'ah termasuk di dalamnya isu yang tidak biasa dipikirkan oleh akuntansi konvensional. Perilaku manusia diadili di hari kiamat. Akuntansi harus dianggap sebagai salah satu derivasi (hisab) yaitu menganjurkan yang baik dan melarang apa yang jelek. Realitas akuntansi syarî'ah adalah tercermin dalam akuntansi zakat.

Kedua, prinsip- prinsip umum akuntansi syarî'ah yang menjadi dasar universal dalam operasional akuntansi syarî'ah, yaitu prinsip pertanggungjawaban, prinsip keadilan, prinsip kebenaran.

Ketiga, operasional bank syarî'ah terdiri dari dua aktivitas utama yaitu kegiatan penghimpunan dana atau pendanaan (funding) dan kegiatan pembiayaan (financial). Terdapat tiga bentuk penarikan dana pihak ketiga yaitu dana titipan (wadi ’ah), partisipasi modal berbagi hasil dan berbagi resiko (non guaranteed account) untuk investasi umum (general investment account/mudlarabah mutlaqah), investasi khusus (special investment account/mudlarabah muqayyadah). Sedangkan kegiatan pembiayaan (financial), di antaranya adalah akuntansi pembiayaan mudlarabah, pembiayaan musyarakah, pembiayaan murabahah, pembiyaan bay' al-salam, dan pembiayaan istishna. Wallâh a'lam bi al-shawâb.

\section{D aftar Pustaka}

A rifin, Zainul. D asar- D asar M anajemen Bank Syariah. Jakarta: A Ivabeta, 2003.

Direktorat Perbankan Syariah Bank Indonesia, Statistik Perbankan Syariah (Islamic Banking Statistik), Desember 2008.

Djakfar, Muhammad. Etika Bisnis Islam Tataran Teoritis dan Praktis. Malang: UIN Malang Press, 2008.

Furywardana, Firdaus. A kuntansi Syariah, M udah dan Sederhana dalam Penerapan di Lembaga Keuangan Syariah. Yogyakarta: Pendidikan dan pelatihan Perbankan Syariah (PPPS), 2009. 
Harahap, Sofyan Syafri. A kuntansi Islam. Jakarta: Bumi A ksara, 1997.

Muhammad. Pengantar A kuntansi Syariah. Jakarta: Salemba Empat, 2002.

Nabhan, Faqih. Dasar-Dasar A kuntansi Bank Syariah, Implementasi PSAK N 0.59 dan Pedoman A kuntansi Perbankan Syariah Indonesia (PA PSI). Yogyakarta: Lumbung IImu, 2008.

Tim Penyusun PAPSI, Pedoman A kuntansi Perbankan Syariah Indonesia. Jakarta: IAI, 2003.

Triyuwono, As'udi. A kuntansi Syariah, M emformulasikan Konsep Laba D alam Kontek M etafora Z akat. Jakarta: Salemba Empat, 2001.

Wiroso, Pengantar Akuntansi Syariah dan Laporan Keuangan Bank Syariah, Makalah disampaikan pada Training of Trainer (ToT) Perbankan syari'ah Bagi Dosen Perguruan Tinggi, Kerjasama Departemen Ekonomi Syari'ah Fakultas Ekonomi, Universitas Airlangga dengan Bank Indonesia, Surabaya, 18- 20 Mei 2010. 